\title{
Biomedical enhancement and social development: a conservative techno-fix
}

\author{
(1) \\ Corresponding Author: Sagar Sanyal \\ University of Melbourne - CAPPE, Philosophy \\ Parkville Campus Melbourne \\ Melbourne, Victoria 3051 \\ Australia \\ Email: sagar.sanyal@gmail.com
}

Sagar Sanyal

Sagar Sanyal PhD is a research fellow at the Centre for Applied Philosophy and Public Ethics at the University of Melbourne. While his researchis primarily in political philosophy, his Marxist and materialist orientation there means he also engages relevant social sciences. Ongoing paper projects include Marxist critiques of the analytic philosophical literature in a variety of debates - the philosophy of war, human enhancement, environmental ethics, theory of justice, and exploitation.

Abstract: Allen Buchanan has argued for a linking of the ethics of human enhancement to the ethics of development more generally. The promise of the 'enhancement enterprise' is that it may help develop society, just as other technological advances have in the past. He proposes a framework of intellectual property rights, government action to ensure the poor can access the enhancements, and an international organization to administer the diffusion of new enhancement technologies from the West to poor countries, and the diffusion within countries to the poorer populations. I take seriously his proposal of discussing biomedical enhancement in terms of the ethics of development. On these grounds of assessment, I argue that his proposal is politically conservative. To make the case, I distinguish conservatism in ethics from conservatism in politics; and I contextualize the proposal against the background of development economics and the neoliberal approach to development.

Keywords: human enhancement , Buchanan , bioliberals, development , bioconservatives

This is the author manuscript accepted for publication and has undergone full peer review but has not been through the copyediting, typesetting, pagination and proofreading process, which may lead to differences between this version and the Version record. Please cite this article as doi:10.1111/ bioe.12277. 


\section{Introduction}

In his 2011 book Beyond Humanity: the ethics of biomedical enhancement, Allen Buchanan examines some justice related issues surrounding biotechnological human enhancement ${ }^{1}$. Against conservatives who consider such enhancement impermissible or undesirable, he argues that they may have significant benefits in the domain of justice. They may contribute to poverty alleviation, economic growth, crime reduction, and more cooperative relations, for instance. He proposes looking at the ethics of enhancement as a dimension of the ethics of economic development. He is sensitive to injustices from unequal access to enhancement technologies, and proposes adding equal access to the responsibilities of government. On an international scale, he addresses the worry that these technologies may not diffuse as fast and as pervasively to developing countries as we might desire. This might worsen inequalities in productivity, or might close off possibilities of developing countries becoming globally competitive in new markets opened up by these technologies. I

welcome the suggestion to treat the ethics of human enhancement debate in relation to the larger debate on development. However, I argue that on this terrain of assessment, Buchanan's proposal is conservative rather than progressive.

Buchanan's book is expansive and broad ranging, and my first step (in section one) is to outline the very narrow set of issues that will occupy this paper. In section two I distinguish conservatism in ethics from conservatism in politics. Section three contextualizes Buchanan's proposal against the background of development economics and the neoliberal approach to development. I make the case that Buchanan's proposals for the enhancement enterprise as a means to development are conservative and not progressive.

\section{Section one: Relevant points from Buchanan Buchanan's general outlook on biomedical enhancements.}

Potentially momentous technological changes are likely in the area of biomedical enhancements. At worst they will enter society through the backdoor - unregulated, with no state policy to ensure equal access, with little oversight of what sorts of enhancements are developed. So it is better to admit them through the frontdoor, with explicit political debate. Then we can design policy about which sorts of enhancements to encourage or discourage; regulate their development, provision and se; have state action to ensure equal access to particularly important and helpful enhancements. We can treat biomedical enhancement as one among many social priorities, and politically negotiate the allocation of resources ${ }^{2}$.

Moreover, society should look forward to an era of biomedical enhancements. Some biomedical enhancements are likely to benefit not only the enhanced individuals, but also society generally. If the enhanced individual is more productive, more intelligent, more cooperative, then this potentially benefits others too ${ }^{3}$.

\footnotetext{
${ }^{1}$ Allen Buchanan, Beyond Humanity? , OUP 2011.

${ }^{2}$ Ibid., p62

${ }^{3}$ Ibid., p35.
} 
The ethics of enhancement should be seen as one important dimension of the ethics of economic development. Economic development, often occasioned by institutional or technological change, has enabled significant improvements in the wellbeing of individuals and extended higher wellbeing across wider sections of society ${ }^{4}$. A consequence of noting the connection to economic development is an appreciation of the importance of institutional design for the ethics of enhancement ${ }^{5}$.

It is worth pausing briefly over the definition of enhancement. Buchanan does not spend long discussing the therapy/enhancement distinction. Medical personnel and infrastructure will likely be involved in biomedical enhancements regardless of whether we determine that medicine ought only to extend as far as therapy ${ }^{6}$. In seeing biomedical enhancements as just another instance of technological development, Buchanan insists that just as the technology of writing allowed humans to do things they could not previously, so too would biomedical enhancement ${ }^{7}$. Accordingly, enhancement is not being defined in contrast to therapy (which might appeal to species-typical or statistical norms of health), but rather in terms of augmenting specific human capabilities. I adopt this understanding of enhancement here ${ }^{8}$.

\section{Buchanan's argument against the conservative}

One might accept the general outlook sketched above and still be conservative about biomedical enhancements, thinking that in general such enhancements are not necessary and should be discouraged as far as possible. I do not mean moral conservatives, who think that certain biomedical enhancements are unnatural and therefore bad, or that pursuing such enhancements is a symptom of a defective moral character. Buchanan ably counters moral conservatives elsewhere in his book, but I am concerned with conservatives who have other reasons for resisting - concerns about unintended side effects of biomedical tampering on the enhanced individual, or about material inequality or social divisions between the enhanced and the unenhanced. Within his general outlook, Buchanan advances an argument to convince this latter sort of conservative ${ }^{9}$.

He formulates the Simple Conservative Argument (SCA): even if the enhancements would increase productivity and potentially also wellbeing, they also carry risks. As we are already quite well off (thanks to past technological advances), the risks are not worth taking. Since the focus is on the level of wellbeing we have already attained, Buchanan's strategy is to note that this only yields an opposition to biomedical enhancement if the SCA assumes that further biomedical enhancements

${ }^{4}$ Ibid., pp37, 45-47.

5 Ibid., p21.

6 Ibid., p27.

7 Ibid., p38.

${ }^{8}$ For more on definitions of enhancement, see David Resnick, 'The moral significance of the therapyenhancement distinction in human genetics', Cambridge Quarterly of Healthcare Ethics, 9.3 (2000): 365-377; and Julian Savulescu, et al. 'Wellbeing and enhancement', Enhancing Human Capacities. Eds. Julian Savulescu, Ruud ter Meulen and Guy Kahane. Wiley Blackwell, 2011. 3-18.

${ }^{9}$ It is unclear whether the liberal/conservative terminology helps or hinders the enhancement debate. If opposition to enhancement were largely based on religious and traditional values, it might make sense to import the terminology from politics to bioethics. However, in Buchanan's use of 'conservative', politically progressive opponents to enhancement also count as conservatives in this sense. For discussion of whether this terminology is helpful, see Ruth Macklin, 'The new conservatives in bioethics: who are they and what do they seek?, Hastings Center Report, 36.1 (2006); Arthur Caplan, 'Good, better, or best?', Human Enhancement. Eds. Julian Savulescu and Nick Bostrom. Oxford: OUP, 2009. 199-210.

34-43 
will not be needed, either (1) to sustain the gains in well-being that many humans have achieved or (2) to make these gains available to those who now lack them ${ }^{10}$.

What makes it difficult to sustain the levels of wellbeing already achieved by the better off, or to extend these levels to all other humans? Buchanan gives some examples: climate change, environmental toxicity, an ageing labour force, the prevalence of violent ideologies and destructive weapons, rapid international transmission of new infectious diseases. He then constructs

imaginative scenarios in which specific threats presented by these factors might be neutralised or mitigated by future biomedical enhancements ${ }^{11}$.

\section{Buchanan's institutional proposals to accompany the biomedical enhancement era}

Buchanan does not merely want to argue that biomedical enhancement may increase productivity and thereby enable increases in levels of wellbeing. He also wants to make such productivity increases more likely and to consider justice aspects of the resulting increases in wellbeing. Looking to the ethics of economic development, he notes three points to consider in the introduction of productivity enhancing technology. One, we must seek conditions under which the adoption of such technology actually increases wellbeing (rather than merely creating necessary conditions for such increases). Two, we must care not only about the increase in aggregate wellbeing, but also about the distribution of this increase across the population. Three, future possibilities of redistribution may be constrained by the process by which technologies emerge and spread. This means that it is naïve to seek to 'maximize innovation' and leave it to a subsequent political process to redistribute the results ${ }^{12}$.

Regarding the first point, he thinks states have an interest in the economic prosperity and welfare of their citizens. There is a difference between a technology or institution being merely available and its being appropriately enough adopted so as to yield the productivity benefits to society. Just as concern for productivity can justify state spending on education, immunization and health care, it ought to justify state spending to promote sufficient adoption of productivity increasing biomedical enhancements ${ }^{13}$.

On the second point, increases in aggregate wellbeing due to productivity increasing enhancements may be inequitably distributed. Some beneficial biomedical enhancement technologies may be too expensive to be accessible to the poor. The state has a role in ensuring that each citizen has the capacity to be an effective participant in social cooperation, and for particularly beneficial enhancement technologies this means ensuring the poor can afford them ${ }^{14}$.

Buchanan's most detailed proposal concerns the third point. Begin by distinguishing the creation issue from the diffusion issue. One, some biomedical enhancement technologies may be particularly suited to reducing inequalities. As an example Buchanan suggests that some cognitive enhancement drugs are most efficacious on the less bright, and may thus be able to mitigate inequalities due to differences in intelligence ${ }^{15}$. In the interests of justice, we can look at the process of technological development to incentivize research on these sorts of enhancements. This is the creation issue. Two,

\footnotetext{
${ }^{10}$ Ibid., p55.

11 lbid., p56.

12 Ibid., pp53-54.

13 Ibid., p50.

14 Ibid., p51.

${ }^{15}$ Ibid., pp247-248.
} 
once some beneficial technology has been developed, the pace and scope of its diffusion matters for justice. If the technology is not widely available to the disadvantaged, we fail to address inequality. If the technology becomes widely available but only very slowly, this presents a problem too. During the time lag, the first-served may build up the means to exclude the latecomers from certain areas of economic cooperation. For instance, the first firm to adopt a technology might build up brand loyalty, economies of scale, links with other parts of the production chain, and experience in using the technology that allows it to undercut or otherwise bar the entry into the market of latecomer firms. This is the diffusion issue.

As a general institution for the creation and international diffusion of beneficial technologies, Buchanan (together with Robert Keohane and Anthony Cole) proposes establishing a Global Institute for Justice in Innovation (GIJI). I will consider the proposal only in relation to the creation and diffusion of biomedical enhancement technologies specifically. The basic problems tackled are familiar from the global justice debate on the inability of the global poor to afford necessary medicines, and pharmaceutical companies' tendency to focus on 'diseases of the rich', rather than 'diseases of the poor'. Incentives are needed for research and development of new technologies. Patents act as incentives, but they allow monopoly pricing, which often places new technologies beyond the reach of the global poor who might benefit from them. Moreover, since the research direction is determined by the prospect of profit, it tends to focus on developments that might appeal to the wealthy, rather than developments which might do more good, but that would have a small and poor target market.

The GIJI idea helps with the creation problem by offering prizes and grants for justice-promoting innovations, and by lengthening patents on such innovations. Its main focus, however, is on diffusion.

The central instrument for this is compulsory licensing. Under current international intellectual property agreements, signatory nations have the power of compulsory licensing for essential medicines under certain conditions: they can grant licenses to firms for the production of such medicines without the permission of the patent holder. Buchanan proposes compulsory licensing for productivity enhancing biomedical enhancements, with the power lying not with member states but with the GIJI. It would be exercised if GIJI is concerned that a beneficial technology is being diffusing too slowly to realize its potential for making significant gains in promoting justice, or is exacerbating existing injustices, in the form of extreme deprivation or basic political and economic inequalities ${ }^{16}$. The speed of diffusion is affected by the royalties charged by (or the price set by) the patent holder, which may price the innovation beyond the reach of the global poor. It is also affected by the patent holder's and manufacturer's distribution networks for the innovation. The licensing option is to be a last resort, the first step is privately notifying producers that they have been placed on a watchlist for slow-diffusing innovations, and the intermediate step being to publicly warn the producers ${ }^{17}$.

\section{Section two: Conservativism in ethics and conservatism in politics}

In this section I want to clear some ideological space for the next section, where I argue the conservatism of the proposal by Buchanan (and Keohane and Cole). Buchanan advocates an

\footnotetext{
${ }^{16}$ Ibid., pp255-256.

${ }^{17}$ Ibid., p257.
} 
enhancement enterprise as a way to improve the lives of the poor and sustain the living standards of the well off. I plan to pursue seriously his suggestion that the ethics of human enhancement should be treated as part of a larger debate on the 'ethics of development'. The academic literature on development is primarily about political economy and sociology (the relevant disciplines go by names like 'development economics' and 'development studies', not the 'ethics of development'). Accordingly, Buchanan's proposal must be assessed from these grounds. We cannot assess it merely on the grounds of an ethical principle - that we must improve the lives of the poor, and that insofar as biomedical enhancement does this, it should be promoted. All plausible development programs will profess the intention of helping the poor. Making that profession does not qualify a view as progressive in development theory. The starting point must be some clarification of the political landscape on which Buchanan's proposal appears.

One of the distinctions that has emerged within the ethics of human enhancement debate, is between bio-liberal and bio-conservative ${ }^{18}$. At its most transparent and apolitical, the distinction is simply between permissive (being called liberal) and restrictive (being called restrictive) attitudes towards biomedical enhancement of particular kinds. The 'liberal' and 'conservative' labels seem to have gotten attached accidentally, because many participants in the debate had also been involved in the bioethics debates on abortion and IVF, where permissive and restrictive positions did map on to these political traditions as expressed in the US.

But overlain on the permission/restriction point is some appeal to the aura of progressivism that accompanies the liberal political tradition - advocacy of the civil and political freedoms, capitalism's contribution to raising productivity through continual technological innovation, its contribution to the wealth of nations, and the expansion of trade and investment to ever-wider regions of the world. A group of philosophers have come to advocate widespread use of human enhancement for cognitive and moral enhancement ${ }^{19}$. They form an important core of the 'bio-liberal' camp, and advocate not only the permissibility of specific biomedical enhancements, but advocate such enhancements as an important tool in progressive social transformation. This group claims intellectual space for the importance of the biomedical industry as a way to address pressing social and political problems of crime, poverty, terrorism and climate change (see below). This core is also one of the drivers for a continuing research program in the ethics of human enhancement, given that the older debates about the very permissibility of biomedical enhancement seem played out.

Speculation in favour of biomedical enhancements is not new to Buchanan, of course. Buchanan echoes Anders Sandberg in remarking that lower IQ is associated with a number of risks including poverty, criminal behaviour and drug addiction, and that cognitive enhancements to IQ might be significant in addressing these issues ${ }^{20}$. Sandberg and Savulescu add the following to this list of correlations: high school dropouts, parentless children, welfare recipiency, out of wedlock births ${ }^{21}$. If

\footnotetext{
${ }^{18}$ For a longer discussion of kinds of bio-conservatism and bio-liberalism, see Alberto Giubilini and Sagar Sanyal, 2014, 'The ethics of human enhancement', Philosophy Compass.

${ }^{19}$ See for instance John Harris , 2007, Enhancing evolution: the case for making better people, Princeton; Neil Levy, 2007, Neuroethics: challenges for the $21^{\text {st }}$ century, CUP; Thomas Douglas, 2008, 'Moral enhancement', Journal of Applied Philosophy, vol 25(3); Ingmar Persson and Savulescu, 2012, Unfit for the future: the need for moral enhancement, OUP; Aubrey de Grey, 2004, 'Escape velocity: why the prospect of extreme human life extension matters now', PLoS Biology, vol2(6).

${ }^{20}$ lbid., p47.

${ }^{21}$ Anders Sandberg and Julian Savulescu, 'The social and economic impacts of cognitive enhancement', in
} 
these sorts of comments are merely meant as arguments in favour of permitting biomedical enhancements, that is fine. However, if they are meant as more substantive arguments for treating the biomedical enhancement industry as a high social priority as a means of tackling serious issues like climate change, terrorism, crime and drug addiction, then we ought to expect higher standards from writers in the debate.

All of these problems have large sociological literatures devoted to them, identifying social causes of these problems and proposing political solutions. Importantly, these literatures tend to suggest changes to the underlying political economy (rather than conserving it). They require addressing phenomena like unemployment; addressing the institutions that maintain divide and rule strategy within working classes (the brunt faced by the most marginalized sections specific to an economy, like migrant workers, women, African Americans, Dalits); the growing inequality within countries; the ease of mobility of capital to find cheaper labor and more lax laws; and imperial wars ${ }^{22}$.

To adopt a technical solution (like cognitive enhancement) over a political solution is a substantive, and politically conservative, program. Charles Murray - a co-author of the work on which Sandberg and Savulescu depend for their data on IQ correlations with poverty, crime and so on - has been a significant intellectual figure on the American political right whose arguments about welfare were influential on just these elements of the Republican policy platform in the Reagan, Bush and Clinton years $^{23}$. Neither Buchanan, nor Sandberg and Savulescu offer a critical appraisal of correlations between IQ and these social ills, nor any discussion of their significance for social policy. Accordingly we do not know their thoughts on how important a role cognitive enhancement might have in alleviating poverty and crime when compared to political means. However, if the ethics of enhancement literature ought to expand to address social priority setting as Buchanan proposes, then it is precisely such comparison with the sociological literature that is wanting.

It is noteworthy that the enhancement debate would be of much less intellectual interest (and would have less ability to win research grants to fund books and postdocs) ${ }^{24}$ if it spoke about actual technologies rather than speculated future inventions. Having taken plenty of Ritalin, Modafinil and SSRIs, I can attest to benefits. But if this is the level of benefit we mean when we speak of cognitive and moral enhancement, then such enhancement really isn't worth the philosopher's ink (and certainly not social or political philosophy rather than ethics)! Politically informed progressives have

Savulescu, Kahane and ter Meulen, Enhancing Human Capacities, Hoboken, Wiley, 2011, p97.

${ }^{22}$ It would be misleading to pull out a handful of sources as representative of such a large area of social science. Instead I select examples that are illustrative, and that transparently bear out my own interests and leanings in social science topics. On 'law and order', see the criminologist David Garland, 2001, The Culture of Control: crime and social order in contemporary society, OUP. On migration, racism and the 'divide and rule' dynamics within the working class, see Liz Fekete, 2009, A suitable enemy: racism, migration, and Islamophobia in Europe, Pluto. On Islamic terrorism, see Aijaz Ahmad, 2008, 'Islam, Islamisms and the West', Socialist Register. On the political implications of easy capital mobility, see Prabhat Patnaik, 2008, 'The accumulation process in the period of globalization', Re-envisioning Socialism, Tulika Books. On neoliberalism generally, see the discussion (and references) below.

${ }^{23}$ Sandberg and Savulescu draw their data from Herrnstein and Murray, The Bell Curve, Free Press, 1994. For critical appraisals of the social policy implications of the book, see Steven Fraser (ed.), The Bell Curve Wars, Basic Books, 1995. See also Ned Block and Gerald Dworkin (eds.), The IQ Controversy, Pantheon Books, 1976, which examines Richard Herrnstein's work from the 1970s which foreshadowed The Bell Curve. In particular, see the interchange between Noam Chomsky and Herrnstein in the latter collection.

${ }^{24}$ I am employed to write this paper as a postdoc, thanks to an Australian Research Council grant awarded to Steve Clarke, Julian Savulescu and Tony Coady, to look at bioconservatism and the human enhancement debate. 
long learnt to be critical of apolitical quick fixes and hobby horses like 'if only everyone could smoke some marijuana or take some acid, they'd see that we're all one big happy family and conflict and selfishness would fade away'. At the risk of 'harshing anyone's buzz', current speculations about moral enhancement stand on no firmer ground than this, and from the point of view of the development debate, they should be called out for it. The sorts of enhancement that enthusiasts have in mind when they speculate about cognitive and moral revolutions are ones which have yet to be researched and developed. These future inventions will somehow tackle poverty, crime, climate change and terrorism. How exactly will they do this? Well, we can't say, as we haven't invented it yet. All we can do for now is point to how today's products can tinker with emotions and attention spans. And on the basis of this, we are to not only permit biomedical enhancements, but to actively support and promote them with social resources.

Since Buchanan contrasts his position to the 'simple conservative', this carries a rhetorical implication that his position is somehow progressive. Indeed, in its professions of intent the aim is humanitarian - faster diffusion of beneficial and injustice-reducing biomedical enhancements to poor countries and poor people. But this trades on a blurring between conservatism on issues of ethics (abortion, IVF) and conservatism in politics. Conservatism in politics is about conserving the institutions of power, often at the cost of the subject classes who bear the brunt of the established order. In our time, the fundamental institutions of power include the state and capital, and the international institutions of trade and investment liberalization. Buchanan's proposal is certainly progressive when contrasted to the ethical conservatism of people motivated by issues like abortion and IVF. However, it is conservative in a political sense.

Properly speaking, it is a liberal account, when liberalism is understood as the political philosophy that arose with the bourgeoisie (progressive as against the feudal status quo) and that now acts to justify (and conserve) contemporary capitalism, together with the preeminent power of the liberal democracies of North America and Western Europe. Liberalism of course is a broad tradition, including social democrats of the Keynesian variety and advocates of state directed development in the third world, as well as advocates of trade and investment liberalization, privatization and austerity. However, the latter variety of liberalism dominates in international policy circles today, and is generally called neoliberalism. Buchanan's proposal fits in the latter category and would have to operate within the neoliberal framework, even though it advocates minor progressive changes within it.

\section{Section three: Appealing to policy-makers with capital-led techno-} fixes

Buchanan is not concerned with a general moral and political understanding of the possibilities of biomedical enhancement. He is concerned with a narrow subset of this, which involves policymaking. His is an exercise in trying to convince high level policy makers in the liberal democracies of places like the US and EU. This strategy requires excluding possibilities deemed unpalatable to the big players, in particular the big business that stand to profit from a potential large new market. He may well think this is strategically or pragmatically the best strategy for helping the poorest, but this is more transparently described as conservative, not progressive. After all, conservatives too claim theirs is the best way to help the poor. Merely making that claim does not make a program progressive. Let me support this with a discussion of Buchanan's proposal. 
Even while explicitly noting that patents create monopolies and thus slow diffusion, Buchanan advocates extending patents for 'injustice-reducing' biomedical enhancements. The power of compulsory licensing is taken away from individual poor countries (as is currently the case under TRIPS) and given to GIJI, a move that he writes would be attractive to leading countries and firms as they would be better placed to challenge compulsory licenses ${ }^{25}$. Further enticement to these leading actors is that GIJI would offer a higher compensation to patent holders than the royalty rate currently given in compensation for compulsory licensing under TRIPS ${ }^{26}$.

These are puzzling proposals if one believes that monopolies slow diffusion, and should be a clue to the audience that Buchanan (and Keohane and Cole) is trying to convince. The obvious place to begin if one were not worried about getting the buy-in of Big Pharma and the attention of policymakers in North America and Western Europe, would have been to oppose the international patent system, and to increase third world sates' power to compulsorily license. There is nothing utopian or radical about this alternative starting point. When TRIPS was being negotiated (and ever since), it was strongly opposed even within policy circles. Third world countries resisted the development of intellectual property rights, rightly noting that the possibility of technology-diffusion by reverse engineering, poaching skilled workers, and industrial espionage was an important part of the industrial catch-up policies of all of the now developed countries ${ }^{27}$. Instead, Buchanan selects a path more acceptable to Big Pharma, largely headquartered in the West, and disproportionately the holder of IPR in the field.

While GIJI is an inventive proposal, when it comes to biomedical enhancements, it is essentially an elaborate workaround for direct government running of the sector. Funding for GIJ is sourced from governments both to run the administrative, monitoring, and dispute resolution structures of GIJI itself, and to compensate patent holders when a patent is compulsorily licensed. Since much basic research in biomedicine and related fields has been funded by governments (through the US National Institutes of Health, for instance) allowing patents on developments founded on such basic research is in some ways a giveaway of a public good to private interests. The obvious progressive alternative would be to move the biomedical research increasingly to the public domain - sustained through state allocation and with no patents ${ }^{28}$. Private interests are welcome to develop the basic research that governments place in the public domain, but do so on condition that the results of their developments are likewise placed in the public domain. This is to adopt one of the models proposed in the Creative Commons and Open Source movements. Private interests nonetheless have some pecuniary incentives for building on the basic research. Innovators enjoy many natural protective mechanisms that allow them to reap financial rewards, such as imitation lag, reputation advantage, and a head start in learning curves ${ }^{29}$.

${ }^{25}$ Buchanan, op. cit., p266-267.

${ }^{26}$ Ibid., p271.

${ }^{27}$ For a discussion of innovation and economic development before the establishment of international patents, see Ha-Joon Chang, 2001, 'Intellectual property rights and economic development: historical lessons and emerging issues, Journal of Human Development, vol 2(2). The paper is also a useful overview of the emergence of the TRIPS agreement, against much opposition from the 'Group of 77 ' developing countries.

${ }^{28}$ For a discussion of the economics of a similar proposal for the pharmaceutical industry in the US, see Dean Baker and Noriko Chatani, 2002 (11 Oct), Promoting Good Ideas on Drugs: Are Patents the Best Way? The Relative Efficiency of Patent and Public Support for Bio-Medical Research, Center for Economic and Policy Research (Briefing Paper), Washington DC.

${ }^{29}$ Chang 2001 op. cit. 
Overall, Buchanan's attitude to the biomedical industry seems to be as follows. He wants to attract private investors to enter this field and undertake basic research, as well as product development, marketing and distribution. But 'attracting investors' is not a politically innocent project. Investors have lots of other opportunities for their investment, whether within the pharmaceutical and cybernetics industries, or more generally across the economy. The reason they would be attracted to the biomedical field is because the rates of return on capital are comparable to those available elsewhere, or that they have guaranteed large markets (as the state will subside the sale of enhancement technologies to the very poor). So, no matter what else it does, the GIJ system of awards for investment in the biomedical industry must attend to this bottom line. His proposal for innovation by biomedical, and consequently the alleviation of social injustices depends on the rate of return as its motive force.

I submit that Buchanan's proposal is best understood in the context of the neoliberal model of economic development in which it is embedded. Indeed, defining the problem set in terms of what changes could be made by policy-makers in powerful Western states, pushes it in this direction. An older model of development prevailed in the third world until the IMF forced liberalization and privatization on countries stricken by the debt crises in the $1980 \mathrm{~s}$ and $1990 \mathrm{~s}$. That model sought to address poverty and economic backwardness by land reform, infant industry protection, protection of vulnerable livelihoods in agriculture, and state spending more generally. The neoliberal model has been to make conditions attractive for international capital, the idea being that investment will generate jobs and incomes ${ }^{30}$.

Buchanan does advocate significant state action in the interests of progressive redistribution, and this creates some divergence from the neoliberal project of letting capital loose. Some beneficial bioenhancement technologies may be too expensive for the poor. The state has a role in ensuring that each citizen has the capacity to be an effective participant in social cooperation, and for particularly beneficial enhancement technologies this means ensuring the poor can afford them. Buchanan thinks states have a stake in raising the productivity of their citizens with education, healthcare, immunization, and so they should have an interest in diffusing biomedical enhancements for similar productivity reasons. However, we should make a point of the political innocence (at best) of suggesting this more than 30 years into a global policy shift, pushed by the leading Western countries, of reducing government spending on education and healthcare. Third world governments have been forced to cut basic supports of life for the poor like food subsidies, let alone government spending on bourgeois hobby horses like the latest techno-fix marketed by capital.

Suppose states could play the progressive redistribution role (rather than being bound by neoliberal constraints on public spending and corporate taxation). Suppose they could marshal the political will to do this (getting the assent of the most powerful political and economic classes, who benefit from political disempowerment of the poor and their cheap labor). But then they could just address poverty more directly through redistributive public spending, and food and medicine distribution.

\footnotetext{
${ }^{30}$ For a variety of critical perspectives on neoliberalism, from social democratic and developmentalist to Marxist, see: Robert Pollin, 2005, The contours of descent, ( ${ }^{\text {nd }}$ ed.), Verso; Ha-Joon Change and llene Grabel, 2004, Reclaiming development: an alternative economic policy manual, Zed Books; Vanessa Ogle, 2014, 'State rights against private capital: the 'New International Economic Order' and the struggle over trade, aid, and foreign investment 1962-1981', Humanity, vol5(2); David Harvey, 2005, A brief history of neoliberalism, OUP; Utsa and Prabhat Patnaik, 2015, 'Imperialism in the era of globalization', Monthly Review, vol 67(3).
} 
There are many already-tested and sociologically better grounded proposals for reducing poverty and crime than speculations about future innovations in biomedical enhancement. Nothing much is added by the subsidy to the biomedical industry. By itself, the flourishing of a biomedical enhancement industry simply serves to grow the national product. Most of the progressive potential depends on the supposition that the state will redistribute the aggregate gains to the poor. Not much work is done by the specific technologies developed in the enhancement enterprise, because we can at best speculate about these, and about their progressive effects. Such speculation is fine for the permissibility debate, but should have little weight in prescribing a development program for eradicating third world poverty (or, for that matter, crime, terrorism and climate change).

Buchanan's policy package advises remedial state action alongside letting capital loose, but the remedies mostly go against current neoliberal policy orientation and so are unlikely to be obtained in the near future. The bulk of the proposed framework however, is to create an investor-friendly climate in biomedical, which is certainly in keeping with current policy outlook, and is thus likely to be the first part of the GIJI to be realised.

I propose we should see the Buchanan proposal as somewhat akin to the Green Revolution idea in the early postwar decades ${ }^{31}$. The Green Revolution was promoted for its potential to reduce world hunger. It involved newly developed higher-yield seeds, together with the agrochemicals and irrigation with which these seeds work best, and greater mechanization in farming. It was pushed by the US in the ex-colonial world to draw populations away from the main alternative of 'red revolution' - peasant-oriented land reform to break up large landholdings and give land to the landless and landpoor (pursued to varying degrees in many third world countries). The problem of hunger in the third world was not (and is not) one of a global shortage of food. Rather it was that the poorest sections (often small farmers) did not have the money to buy the food that was already available. Thanks to the efforts of the global grain oligopolies, the produced food grains found their way to richer compatriots or foreign consumers who were already well-nourished (often via the detour of becoming animal feed for meat production). Land reforms were meant to deliver greater wealth to poorer sections of the peasantry, to free them of land tenancy relations that drained their income, and to allow poor sections of the peasants to satisfy their basic nutritional needs largely from their securely-held plot of land rather than having to secure food through the market, which is subject to global price and income volatility.

The Green Revolution promised to alleviate hunger and poverty by yoking technology to the profitseeking of capital. Food grains output did rise in many places, but the overwhelming effects were the gradual consolidation of Western seed and agrochemical companies, and the ejection of poorer sections of peasants from their livelihoods. Farmers undertook debt to buy the new seeds and other capital inputs required to make them work as advertised. Bigger farmers benefited most, as they could most easily access credit to enlarge operations. Many small farmers grew over-indebted and when they were forced from their land, this consolidated the landholdings of big farmers and moneylenders who took over securitized land. Its effect was to conserve the basic political economy

\footnotetext{
${ }^{31}$ Utsa Patnaik and Sam Moyo, 2011, The agrarian question in the neoliberal era: primitive accumulation and the peasantry, Pambazuka Press; Utsa Patnaik, 2003, 'Global capitalism, deflation and agrarian crisis in developing countries', Journal of agrarian change, vol3; Harriet Freidmann, 2005, 'Feeding the empire: the pathologies of globalized agriculture', Socialist Register; Frances Moore Lappe, Joseph Collins and Peter Rossett, 1998, World Hunger - twelve myths, Grove Press.
} 
- the owners of land and owners of money do not concede any power to the peasants. The major lessons of the Green Revolution for the left in development studies have been that productivityraising technological fixes are not a substitute for political change; that they can masquerade as progressive change simply by virtue of increasing productivity (with the gains somehow trickling down to the poor without need for political change); and that they are a useful vehicle for powerful states to create foreign markets for their corporations. Like the Green Revolution, the enhancement enterprise is a capital-led techno-fix to poverty. Like the Green Revolution, it is conservative of the political economy, as compared to other proposals for poverty alleviation that include land reforms, infant industry protection, and greater public spending.

\section{Conclusion}

Buchanan's proposal occupies an odd place, perhaps a cost of making the innovative connection between the debates on the ethics of human enhancement and on the ethics of development. As a proposal for development, I argue it has little to recommend it. I fail to see why politically informed progressives, with some understanding of sociology and political economy, should have any interest in Buchanan's proposal for alleviating poverty, combating terrorism, reducing crime or coping with climate change by the capital-led techno-fix. Not that they should have anything against Buchanan's idea. It is laudable, just as any appeal to do good is laudable. But that is a low threshold for a political program. As a practical program for progressives, there are far more promising avenues already

available in critical sociology, political economy, development studies and activism.

So who would be interested in Buchanan's proposal? Pharmaceutical companies, for one. And, as with the Green Revolution, states that want another give-away to business that they can cloak in pro-poor language.

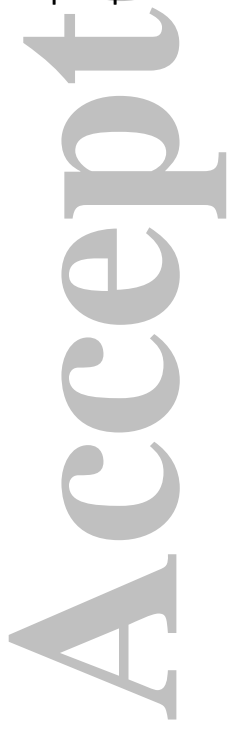




\section{University Library}

\section{- M M I N E R VA A gateway to Melbourne's research publications}

Minerva Access is the Institutional Repository of The University of Melbourne

Author/s:

Sanyal, S

Title:

BIOMEDICAL ENHANCEMENT AND SOCIAL DEVELOPMENT: A CONSERVATIVE TECHNOFIX

Date:

2016-11-01

Citation:

Sanyal, S. (2016). BIOMEDICAL ENHANCEMENT AND SOCIAL DEVELOPMENT: A CONSERVATIVE TECHNO-FIX. BIOETHICS, 30 (9), pp.733-740. https://doi.org/10.1111/ bioe.12277.

Persistent Link:

http://hdl.handle.net/11343/291768 